\title{
Biochemical Response and Nutrient Uptake of Two Arbuscular Mycorrhiza-Inoculated Chamomile Varieties Under Different Water Potentials
}

Fatemeh Ebrahimi

Yasuj University: Yasouj University

Amin Salehi ( $\square$ aminsalehi@yu.ac.ir)

Yasuj University: Yasouj University

Mohsen Movahedi Dehnavi

Yasuj University: Yasouj University

Amin Mirshekari

Yasuj University: Yasouj University

Mohammad Hamidian

Yasuj University: Yasouj University

Saeid Hazrati

Azarbaijan University of Tarbiat Moallem: Azarbaijan Shahid Madani University

Original Article

Keywords: Funneliformismosseae, Matricariachamomilla, Nutrient uptake, Water-deficit stress

Posted Date: June 16th, 2021

DOI: https://doi.org/10.21203/rs.3.rs-600084/v1

License: (1) This work is licensed under a Creative Commons Attribution 4.0 International License.

Read Full License 


\section{Abstract}

\section{Background}

Water-deficit stress is one of the most important sources of damage to crop production worldwide. Adopting appropriate varieties using soil microorganisms such as arbuscular mycorrhiza(AM) can significantly reduce theadverseeffectsofwater deficiency.This study is aimed to evaluate the role of Funneliformismosseaeon nutrients uptake and some physiological traits of two chamomile varieties namely Bodgold (Bod) and Soroksári(Sor) under water-deficit stress. The pot experiment was performed in a hydroponic system within a completely randomized design considering four replications. Three levels of water-deficit stress (PEG 6000) were taken into account at water potentials of -0.4 and $-0.8 \mathrm{MPa}$. The second factor was AM inoculation.

\section{Results}

Water-deficit stress significantly reduced the uptake of macro-nutrients $(\mathrm{N}, \mathrm{P}$, and $\mathrm{K})$ and micro-nutrients ( $\mathrm{Fe}, \mathrm{Cu}, \mathrm{Mn}$, and $\mathrm{Zn}$ ) in the shoots and roots. Moreover, the level of osmolytes (total soluble sugars and proline) and the activity of antioxidant enzymes in the shoots of both varieties increased under waterdeficit stress. In the case of Sor variety, the level of these compounds was more satisfactory. AM improved plant nutrition uptake and osmolyte contents while enhancing antioxidant enzymes and reducing theadverseeffectsofwater-deficit stress. Under water-deficit stress, the growth and total dry weight improved upon AM inoculation.

\section{Conclusions}

In general, inoculation of chamomile with AM balanced the uptake of nutrients increased the level of osmolytes, antioxidant enzymes, and hence improved plant characteristics under water-deficit stress in both varieties, however, it was more effective in reducing stress damages in Sor variety.

\section{Introduction}

The use of herbal medicinal products and supplements has tremendously increased over the past three decades. More than $80 \%$ of the world's population rely on these products as a part of primary healthcare (Sharma 2004; Ekor et al. 2014). German chamomile (Matricaria chamomilla L.) belongs to the family of Asteraceae, one of the most common medicinal plants (Wichtl 2004). Chamomile is a prominent medicinal plant whose compounds are considered safe (Sharifi et al. 2014). German chamomile flower and its extracts have antimicrobial and antioxidant activity and have been used as a painkiller, antianxiety, antispasmodic, anti-inflammatory, and anti-gastrointestinal agent (Rehmat et al. 2020). With the increase in the global demand for medicinal plants, there is an urgent need to increase their cultivation and production. Water-deficit stress (due to global warming and climate change) is the main cause of the decremented annual plant performance. In arid and semi-arid regions, plants are exposed to water-deficit stress due to the simultaneous increase in the rate of transpiration and temperature and the reduction of 
the root access to water (Halo et al. 2020). Iran has a dry and semi-arid climate with an average annual rainfall below a third of the global average (Madani et al. 2016). The increasing demand for medicinal plants, especially chamomile, necessitates deeper knowledge to adopt drought-resistant varieties. In addition to water management, the selection of the right genotype can also contribute to preventing water-deficit stress damages and promoting sustainable use of water resources. Concerning medicinal plants, although water-deficit stress increases the synthesis of secondary metabolites, it can also decline the growth of the plant especially its vegetative and reproductive organs (biomass) which generally contain medicinal compounds (Selmar et al. 2017). It also reduces the nutrient uptake of chamomile (Salehi et al. 2018), which plays a vital role in its total dry weight and essential oil content (Andrzejewska et al. 2014). Under water-deficit stress, lipids, proteins, and nucleic acids are damaged due to the rise in the content of reactive oxygen species (ROS) (Uzilday et al. 2012). Plants exploit effective systems such as antioxidants enzymes catalase (CAT), superoxide dismutase (SOD), ascorbate peroxidase (APX) and osmolytes such as soluble sugars to combat toxic ROSs and reduce their consequent damages (Al-Arjani et al. 2020).

As one of the commercial varieties of chamomile tetraploid, Bodgold (Bod) has shown favorable performance in terms of total dry weight and essential oil among other types of diploid and tetraploid chamomile (Banatska (2x), Lutea (4x), Zloty Lan (4x), and Goral (4x)) (Tsivelika et al. 2018). Soroksári (Sor) is another important and diploid variety of chamomile with a desirable essential oil content compared to Lutea, Goral (tetraploid), and Bona (diploid) varieties according to Gosztola et al. (2010). Heretofore, no comparative study has been carried out to explore the activity of antioxidant enzymes, absorption of nutrients, and dry weight of these varieties under stress conditions. Nonetheless, a study reported an increase in proline and antioxidant activity of the Bod variety under water-deficit stress (Benabdellah et al. 2011). Arbuscular mycorrhizal (AM) fungi coexist with the root of most plants and have exhibited great potential for counteracting environmental stresses, as they can increase the availability of plants to a larger volume of the rhizosphere and also improve water and nutrients uptake (Zhang et al. 2018) via morphological change of root volume and through their hyphae (Hameed et al. 2014). On the other hand, these fungi enhance the nutrient uptake by increasing the synthesis of compounds and enzymes involved in the absorption process, such as phosphatase (Hu et al. 2013). Improving the nutrients and water absorption by AM promotes plant growth and reduces the adverse effects of water-deficit stress caused by PEG (Benabdellah et al. 2011; Wu et al. 2013). The beneficial effects of AM have been reported in many Asteracea families under water-deficit stress. For instance, under water-deficit stress condition, AM improves the absorption of macro and micro-nutriments and increments the total dry weight of plants from the Asteracea family, including Echinacea angustifolia (Attarzadeh et al. 2019), German chamomile (Benabdellah et al. 2011), Helianthus annuus (Gholamhoseini et al., 2013), Marigold (Asrar and Elhindi 2011), Safflower (Abbaspour et al. 2010) and Scabious (Knautia arvensis) (Doubková et al. 2013). AM also improves growth and yield in Echinacea angustifolia by increasing the defensive level of antioxidant (catalase and peroxidase) and osmolyte (proline) enzymes (Attarzadeh et al. 2019). This study is an attempt to study the effect of water-deficit stress on nutrients levels (roots and shoots) and the activity of antioxidant enzymes and osmolytes in 
two chamomile varieties. Moreover, the influence of this factor was compared in these two varieties to determine a more resistant one. Additionally, the effect of Funneliformis mosseae on reducing the impact of water-deficit stress was explored in terms of physiological traits and nutrients uptake.

\section{Materials And Methods \\ 2.1 Experimental design}

A pot experiment was performed in the factorial arrangement within a completely randomized design with four replications in the research greenhouse of the Faculty of Agriculture, Yasouj University. The greenhouse temperature was $25 \pm 2^{\circ} \mathrm{C}$. Water-deficit stress was tested at three water potentials (control, -0.4 , and $-0.8 \mathrm{MPa}$ ). Different levels of water-deficit stress were prepared using polyethylene glycol 6000 (PEG) via the formula proposed by Michel and Kaufman (1973) and applied to the Hoagland solution. The second studied factor was the use of arbuscular mycorrhiza (AM) fertilizer (Funneliformis mosseae species (fungal and non-fungal)) which was initially inoculated in the culture medium. In mycorrhizal plants, each pot of mycorrhizal treatment received $40 \mathrm{~g}$ of AM inoculant (containing spore numbers of $120 \mathrm{~g}^{-1}$ substrate) at a depth of $5 \mathrm{~cm}$ and incorporated well with the soil below. Two German chamomile varieties (Bodgold (Bod) and Soroksari (Sor)) were considered. The Bod variety seeds were purchased from Isfahan Agricultural and Natural Resources Research Center while the Sor variety was supplied from Yasouj Zardband Company. To produce seedlings, the seeds were first transplanted in a bed of peat moss and cocopeat (1: 2) in a 72-cell (30 cc) seedling tray. At the 4-6-leaf stage, they were transferred to plastic pots with a height of $25 \mathrm{~cm}$ and a diameter of $18 \mathrm{~cm}$ (6 seedlings per pot), filled with perlite. During the transplanting phase, a quarter of Hogland's solution was used for irrigation. Drought stress was gradually applied after transferring 4-6 leaf seedlings in full Hogland solution with irrigation water for one week. From the second week, the stress levels were applied once every three days for 21 days. The $\mathrm{pH}$ of the solutions was adjusted to $5.8 \pm 0.1$ before each irrigation. It should be noted that all the seed-starting containers, pots, and seedling beds were decontaminated with a greenhouse autoclave, and distilled water was used to make all the nutrient solutions.

\subsection{Sampling to measure dry weight, physiological, and nutrients traits}

21 days after water-deficit stress, two plants were selected from each pot, and young upper leaves were sampled to measure physiological traits. The samples were transferred to the laboratory after being placed in a liquid nitrogen container where they were stored at $-40^{\circ} \mathrm{C}$. To measure the traits associated with the dried sample, four plants were harvested from each pot and dried at $70^{\circ} \mathrm{C}$ for 48 hours.

\subsection{Enzyme activity}

To prepare the enzymatic extract, $3 \mathrm{ml}$ of extraction buffer $(100 \mathrm{mM}$ potassium phosphate at $\mathrm{pH}=7.8,0.1$ M EDTA, and $0.1 \mathrm{M} \mathrm{PVP}$ ) was homogenized with $0.1 \mathrm{~g}$ of leaf sample using a mortar in an ice bath. The obtained homogeneous samples were centrifuged for 30 minutes (14000 rpm at $\left.4{ }^{\circ} \mathrm{C}\right)$ and the 
supernatant was used to measure the enzymes activity. Catalase (CAT) activity was evaluated by monitoring the reduction of the absorption of hydrogen peroxide in the reaction mixture at $240 \mathrm{~nm}$ using a spectrophotometer (Aebi 1984). Peroxidase (POD) activity was also assessed according to the absorption of the reaction mixture (enzymatic extract, potassium phosphate buffer, and guaiacol along with $30 \% \mathrm{H}_{2} \mathrm{O}_{2}$ ) at $470 \mathrm{~nm}$ (Zhou and Leu 1999). Polyphenol oxidase (PPO) activity was measured based on the intensity of the orange color of methyl catechol at a wavelength of $420 \mathrm{~nm}$ produced in the reaction mixture (Kahn 1975). The CAT, POD, and PPO activity of the extract was expressed as enzyme unit $\mathrm{mg}^{-1}$ protein $\mathrm{min}^{-1}$. One unit of enzyme activity is defined as the amount required to decompose $\mu \mathrm{l}$ mol of the substrate within one min.

\subsection{Determination of proline content}

To determine the amount of proline in the shoot, $0.1 \mathrm{~g}$ of fresh tissues were homogenized with $10 \mathrm{ml}$ of 3 $\%$ aqueous sulfosalicylic acid followed by centrifugation. Two milliliters of the supernatant were blended with acid ninhydrin and glacial acetic acid (two milliliters of each). The mixture was kept in a water bath for $1 \mathrm{~h}$ at $100^{\circ} \mathrm{C}$. The reaction mixture was then extracted with toluene (four milliliters) whose absorbance was determined at $520 \mathrm{~nm}$ after cooling down to room temperature (Lechasseur and Paquine 1979).

\subsection{Determination of total soluble sugar}

Total soluble sugar was determined based on the method specified by Irigoyen et al. 1992. Fresh leaves $(0.1 \mathrm{~g})$ were added to $5 \mathrm{ml}$ of $80 \%$ ethanol in a water bath and heated for 1 hour at $80^{\circ} \mathrm{C}$. Then, $1 \mathrm{ml}$ of the sample extract was taken to another set of test tubes and mixed with $1 \mathrm{ml}$ each of $18 \%$ phenol and distilled water. They were then allowed to stand at room temperature for an hour. Finally, $5 \mathrm{ml}$ of sulfuric acid was added and the whole mixture was vortexed. The absorbance was read at $490 \mathrm{~nm}$ using a UV spectrophotometer. Ethanol $80 \%$ was used as a blank sample. Absorbance was recorded at $625 \mathrm{~nm}$ using a spectrophotometer.

\subsection{Measurement of nutrients}

The extract for measuring nutrients was prepared based on digestion by the $\mathrm{H}_{2} \mathrm{SO}_{4}$-salicylic acid- $\mathrm{H}_{2} \mathrm{O}$ method. This extract was employed to measure nitrogen(N) (Novozamsky et al. 1974), manganese Mn (Atomic Absorption), potassium (K) (Film Photometer) (Knudsen et al., 1982), and phosphorus (P) (Røtset 1984) contents. To measure iron (Fe), zinc (Zn) and copper (Cu), the samples were placed at $500 \circ \mathrm{C}$ for 4 h, $5 \mathrm{ml}$ of 2 normal hydrochloric acids $(2 \mathrm{n})$ was added to the samples and placed on the heater. The concentration of $\mathrm{Fe}, \mathrm{Zn}$, and $\mathrm{Cu}$ in the shoot and root of the plant was determined by the atomic absorption (Chapman and Pratt 1961).

Statistical analysis was carried out by SAS software 9.1 and the graphs were drawn by Excel 2013 software while correlation matrices were prepared using xlstat. Comparison of means was performed using the LSD at a P-value of $5 \%$. In the case of significant interaction, LS means procedure was used to compare significant interactions. 


\section{Results}

\subsection{Content of macro-nutrients $(\mathrm{N}, \mathrm{P}$, and $\mathrm{K})$ in roots and shoots}

The three-way interaction between different levels of drought stress, mycorrhiza, and variety was significant on the nitrogen $(\mathrm{N})$ and phosphorus $(\mathrm{P})$ contents of the shoot (Table 1). However, the $\mathrm{P}$ and $\mathrm{N}$ contents of roots and potassium $(\mathrm{K})$ level of the shoot and root were evaluated based on their significance at the $5 \%$ level as interaction and main effects (Table 1). Water-deficit stress reduced $\mathrm{N}$ accumulation in the shoot. High levels of water stress $(-0.8 \mathrm{MPa})$ significantly declined these nutrients uptake in Bodgold (Bod) variety. Regardless of AM application, the $\mathrm{N}$ content of the shoot of the Soroksári (Sor) variety was much higher than the Bod variety; nonetheless, the difference got more evident under water stress; so that the $\mathrm{N}$ content of the shoot of Bod was $4 \%$ lower than Sor variety for + AM treatment. Under stress at an osmotic potential of -0.4 and $-0.8 \mathrm{MPa}$, this value reached 13 and $35 \%$, respectively (Table 3). The water stress also reduced the $\mathrm{N}$ content of the root, but AM partially increased the content of this nutrient uptake in the roots under stress and control conditions. Also, the $\mathrm{N}$ content of the root of both varieties was almost the same. However, the effect of AM on increasing the content of this nutrient was higher in Sor as compared with the Bod variety (Table 4). AM reduced the adverse effects on the $\mathrm{P}$ content of shoot. At the water potential of -0.4 and $-0.8 \mathrm{MPa}$, the impact of AM on the amount of $\mathrm{P}$ in shoot was higher in the Bod variety. Regarding the + $\mathrm{AM}$ treatment, the $\mathrm{P}$ content of shoot of the Bod variety was 20 and $27.5 \%$ at the stress level of -0.4 and $-0.8 \mathrm{MPa}$, respectively. In the case of Sor variety, this parameter was 12 and $10 \%$ higher during the -AM treatment. In general, the P level of the shoot of the Bod was lower than the Sor variety, so that the highest P content of the shoot of the Sor variety was observed upon AM inoculation (Table 3). The P content of the root also decreased with a reduced amount of osmotic potential. The $\mathrm{P}$ amount of root was higher in Sor variety. With increasing stress, the mentioned difference declined as the P content of Sor root was $25 \%$ under control condition, which decremented to 11 and $3 \%$ at osmotic potentials of -0.4 and $-0.8 \mathrm{MPa}$, respectively (Table 5). According to Table 4, AM caused a $12 \%$ enhancement in the P content of the root. Water-deficit stress increased the $\mathrm{K}$ level of shoots and roots. At non-stress conditions, the K content of the shoot of the Sor was $10 \%$ higher than the Bod variety. By enhancing the stress rate, the difference narrowed so that the $\mathrm{K}$ content of the shoot did not significantly differ between the two varieties at a water potential of $-0.8 \mathrm{MPa}$. According to the mean comparison of the main effects of the treatments (Table 4), AM generally increased the $\mathrm{K}$ content of shoot in the chamomile by $9 \%$. Both water stress and AM treatments enhanced the $\mathrm{K}$ content of the root; where the Sor variety exhibited higher root $\mathrm{K}$ content. As already stated, AM increased the root $\mathrm{K}$ content. Under stress conditions, this increase was more profound, so that the potassium content of the AM-inoculated roots was respectively $17 \%, 25 \%$, and $19 \%$ higher than the nonAM treatment under normal (Control) and water potential of -0.4 and $-0.8 \mathrm{MPa}$ (Table 5).

\subsection{Content of micronutrients $(\mathrm{Fe}, \mathrm{Zn}, \mathrm{Mn}$, and $\mathrm{Cu})$ in roots and shoot}


The three-way interaction between different water-deficit stress levels, AM, and the variety was significant only on the Fe content of the shoot (Table 1). However, comparisons between iron (Fe), zinc (Zn), and copper $(\mathrm{Cu})$, and manganese $(\mathrm{Mn})$ contents of the roots and other micro-elements in the shoot were evaluated based on the significance level of $5 \%$ for the main effects and the two-way interaction effects (Tables 4 and 5). Water-deficit stress reduced the Fe content of the shoot in both varieties; however, AM significantly increased the amount of this nutrient at all levels. In comparison with -AM, + AM enhanced the Fe content of the shoot of the Bod variety by $12 \%, 12.5 \%$, and $44 \%$ under water-deficit water potentials of $0,-0.4$, and $-0.8 \mathrm{MPa}$, respectively. Moreover, the Fe content of Sor was correspondingly increased by $5 \%, 22 \%$, and $29 \%$ (Table 3). AM also incremented the accumulation of Fe in the roots of these plants under stress conditions. On the other hand, the Fe content of the roots of the two studied varieties was not significantly different under normal conditions. A reduction in the osmotic potential declined the $\mathrm{Fe}$ content of root in both varieties, nonetheless, its effect was more significant on the Bod variety (Table 5).

Water-deficit stress reduced the Cu content of the shoots (Table 3). At normal conditions, there was no significant difference between the Mn content of the shoots of the two varieties. A decline in $\mathrm{Mn}$ of the shoot of the Bod variety was observed at all levels. The reduction of this nutrient was observed in the shoot of the Sor variety only at the level of $-0.8 \mathrm{MPa}$. The $\mathrm{Mn}$ and Cu levels of the shoots in both varieties did not significantly differ, but AM increased the content of both nutrients, with a higher rate of increase in the shoot of the Sor variety. Water-deficit stress reduced $\mathrm{Mn}$ and Cu contents of the root. Under both stress and normal conditions, the level of these nutrients was higher in Sor root (Table 5). AM also increased the $\mathrm{Zn}$ level of the shoot under osmotic stress conditions. The $\mathrm{Zn}$ content of the shoots was higher at a water potential of -0.4 and $-0.8 \mathrm{MPa}$ as compared with the control condition. Regarding the root, the trend was the opposite, and under water-deficit stress, the root content of these nutrients was less than the controls. Also, the $\mathrm{Zn}$ level of shoot was higher in the Sor variety under all conditions, nonetheless, this was significant in normal and water potential of $-0.4 \mathrm{MPa}$ (Table 5). AM inoculation increased the $\mathrm{Zn}$ content of chamomile by $16 \%$ in (Table 3). There was no significant difference between the Mn contents of the shoots of the two varieties under normal conditions. A decrease was, however, observed in the Mn level of the Bod at all stress levels, nonetheless, the decrease in Mn content of the shoot of Sor was observed only at the stress level of -0.8 MPa. AM enhanced the Mn and Cu levels of the shoots of the Sor and Bod varieties although their difference was not significant. Water-deficit stress reduced $\mathrm{Mn}$ and $\mathrm{Cu}$ contents of the root, the level of these nutrients was higher in Sor roots than Bod under stress and control conditions. AM also increased the $\mathrm{Zn}$ content of the shoot under osmotic stress conditions. Result showed, the $\mathrm{Zn}$ amount of the shoot was higher than that of controls at a water potential of -0.4 and $-0.8 \mathrm{MPa}$. Concerning the root, the trend was the opposite, as the amount of these nutrients in the root was less than the controls. Also, the $\mathrm{Zn}$ content of Sor shoot was higher than that of Bod in all conditions, which was significant under normal and water potential of $-0.4 \mathrm{MPa}$.

\subsection{Osmolytes}

According to the result (Table 2), the three-way interaction of variety, water-deficit stress and AM significantly affected the proline level, whereas, the amount of total soluble sugar was affected by the 
interaction of water-deficit stress $\times$ variety and water-deficit stress $\times$ AM. The water-deficit stress generated by PEG increased the levels of proline and total soluble sugar in both varieties. The highest level of these osmolytes was observed in the osmotic potential of $-0.8 \mathrm{MPa}$. The proline level of Sor was higher than Bod variety in all treatments. Also, in stress and non-stress conditions, the total soluble sugar content of Sor was more than that of Bod. Under stress conditions, AM increased the amount of proline in both varieties, however, its effect on increasing the osmolyte was more evident in the case of Bod variety. An increase was also observed in the amount of total soluble sugar of the AM-inoculated samples at different osmotic potentials (Fig. 1).

\subsection{The activity of antioxidant enzymes}

The three-way interaction of water-deficit stress, AM, and variety was significant on the levels of POD, PPO, and CAT enzymes (Table 2). Water-deficit stress increased the activity of all three enzymes relative to the non-stress conditions. Under stress conditions, the activities of CAT and PPO were higher in Sor as compared with Bod variety. Under stress conditions, the activity of the POD enzyme in Sor variety was higher. AM also enhanced CAT and POD at control conditions as well as water potential levels of -0.4 and - 0.8 MPa. The uppermost activity of these enzymes was observed in both varieties upon AM inoculation under the stress potential of $-0.8 \mathrm{MPa}$. For both varieties, the uppermost activity of these enzymes was observed in AM inoculation and the stress potential of $-0.8 \mathrm{MPa}$. Although the level of PPO enzyme in the stress condition was higher than the control, the highest activity was observed under water-deficit conditions (-0.4 MPa) in AM-inoculated plants (Fig. 2).

\subsection{Dry weight of root and shoot}

A significant three-way interaction was observed regarding water-deficit stress, AM, and variety on the dry weight of root and the shoot (Table 2). The water-deficit stress reduced the dry weight of the root and shoot (Fig. 3). On the other hand, AM + decremented the adverse effect of osmotic potential and increased root dry weight. AM + treatment, at all levels, led to higher shoot and root dry weight as compared with AM-treatment. In general, AM improved the dry weight of chamomile at different water potential levels. With decreasing the osmotic potential, shoot dry weight was declined so that the highest shoot dry weight was obtained in PEG $0, A M+$, and Sor variety (Fig. 3).

The correlation analysis (Fig. 4) showed a strong correlation between different nutrients uptake and the dry weight of chamomile. For example, $\mathrm{P}$ and $\mathrm{N}$ contents of the shoot and $\mathrm{Mg}, \mathrm{Fe}$, and $\mathrm{Cu}$ levels of root showed a slightly positive and significant correlation with shoot dry weight. In chamomile, the content of each nutrient showed some relations with the uptake of other nutrients and most of these correlations were synergistic (positive). For example, a slightly positive and significant correlation was observed between the $\mathrm{Mg}, \mathrm{P}, \mathrm{N}, \mathrm{Cu}$, and Fe nutrients of the shoot. Moreover, the $\mathrm{Mg}$ and $\mathrm{P}$ contents of the root, in addition to being highly correlated with each other, showed a positive correlation with other nutrients uptake such as $\mathrm{N}, \mathrm{Fe}$, and $\mathrm{Cu}$ of shoots and roots. Although the effect of the nutrients on each other was more synergistic, but a significant negative correlation was also observed between the shoot and root as well as between $\mathrm{K}$ and $\mathrm{N}$ contents of the shoot. 


\section{Discussion}

Under water-deficit stress, the uptake of many nutrients declines due to reduced nutrient mass flow and diffusion (Zhao et al. 2020). Our results and other studies showed that osmotic stress caused by PEG impairs the uptake of micro and macronutrients (Mouradi et al. 2016). Although AM improved nutrient levels and reduced the stress damage by expanding root depth and more soil access through their hyphae, the variation trends of the uptake, accumulation, and transfer of nutrients vary in different species of plants and AM under water-deficit stress condition. In many studies, AM has reported to increases the uptake of nutrients such as $\mathrm{N}$ (Hashem et al. 2019), P (Zardak et al. 2018), K (Zhao et al. 2015), Cu, Zn, Fe (Abbaspour et al. 2012), and Mn (Wu and Zou 2009) under the water-deficit condition in different plants. Moreover, AM can affect the uptake of nutrients by producing different compounds. For instance, AM increased the amount of $\mathrm{P}$ absorbed by plants via increasing the activity and production of enzymes such as phosphatase (Hu et al. 2013). It has been shown that AM not only improved the P uptake but also increased the uptake of $\mathrm{N}$ and nutrition in the plant through enhancing the hydraulic conductivity of the root under water-deficit stress (Gholamhoseini et al. 2013; Kong et al. 2014).

Another compound produced by AM is chelating agents such as siderophores, which can ameliorate the uptake of micro-nutrients such as $\mathrm{Zn}$ and $\mathrm{Fe}$ in the plants (Dehghanian et al. 2018). Although some studies have shown that increasing the concentration of $\mathrm{P}$ by mycorrhiza has a positive effect on the $\mathrm{Zn}$ content, but another reason for the increase in the amount of $\mathrm{Zn}$ in the roots and shoots of mycorrhizaeinoculated plants is the rise in the diffusion-limited process of Zn (Lehmann et al. 2014). By increasing the osmotic potential, the pores will be closed which will reduce transpiration and imbalance the active transport, thereby reducing the transfer of nutrients from the root to the shoot (Silva et al. 2009) while increasing the $\mathrm{K}$ content of the shoot by mycorrhizae stimulated the stomata and improved the transport of nutrients from the roots to the shoots (Ruiz-Lozano and Azcón 1995).

The increased activity of POD, CAT (Uzilday et al. 2012) and PPO (Thipyapong et al. 2004) enzymes under stress condition indicated their crucial role in enduring water-deficit stress. CAT has been considered as the most indispensable enzyme for counteracting the hydrogen peroxide produced under stress conditions (Khanna-chopra and Selote 2007). POD is among the major $\mathrm{H}_{2} \mathrm{O}_{2}$-binding enzymes in cytosol and chloroplasts whose level also rapidly increases rose under water-deficit stress. Under waterdeficit stress, an increment was observed in the CAT and POD activities in diverse members of the Asteraceae family, such as Silybum marianum (Nouraei et al. 2018), Carthamus tinctorius L (Chavoushi et al. 2019), Helianthus annuus $L$ (Ghobadi et al., 2013). In line with our results, other studies have also reported that AM has increased the levels of POD and PPO (Meddich et al. 2015; Tyagi et al. 2017) in various plants under water-deficit stress. One of the reasons for the increase in POD enzyme by AM could be the expression of its encoding genes in inoculation with AM (Mustafa et al. 2017). Although CAT is a metalloenzyme and thus its activity depends on the availability of metal nutrients (Armada et al. 2016), in the present study, AM improved the uptake of metal nutrients; however, the effect of mycorrhizal inoculation on CAT enzyme levels under stress conditions was very different and depended on the plant species and even the species of mycorrhizal fungi (Wu and Zu 2009). The increase in CAT activity by $F$. 
mosseae (Amiri et al. 2015) and other species has been reported in many plants under water-deficit stress (Aalipour et al. 2020; Al-Al-Arjani et al. 2020). Osmolytes such as total soluble sugars and proline increased under water-deficit stress; playing a significant role in regulating the osmotic potential of the plant (Khan et al. 2015). Proline is an amino acid and can be stored in the cytoplasm, which in addition to osmotic regulation of the cell, detoxifies ROS and protects membrane integrity and stabilizes proteins/enzymes, and serve as one of the plant's solutions to reduce stress damage (Ashraf et al. 2007). In the current study, the increased leaf proline level was observed by Funneliformis mosseae under waterdeficit stress.

The increase in proline content can be assigned to the effect of $\mathrm{AM}$ on increasing the $\mathrm{N}$ content of the plants under water-deficit stress (Augé 2001). High N levels in the plant under water stress can significantly influence the genes involved in proline biosynthesis which finally increase proline (Monreal et al. 2007; Wang et al. 2011). In another study, an increase was reported in total soluble sugar under drought stress conditions, which is consistent with our results (Al-Arjani et al. 2020). AM increased the level of total soluble sugar in plants as it increased the activity of sucrose-metabolized enzymes which had a positive and significant relationship with glucose, fructose, and sucrose contents (total soluble sugars) (Wu et al. 2017). As observed, under water-deficit stress, plant growth decreased due to reduced osmotic regulation ability, disruption of the solute uptake system, disturbance of osmotic balance, and excessive energy requirements to produce osmolytes (Munns et al. 1993). Based on the findings of this study, a loss was observed in the dry weight of shoots, roots, and flowers of chamomile under waterdeficit stress (Baghalian et al. 2011). One of the causes of reduced chamomile growth under stress may be the osmoregulation imbalance and the disruption in the salt absorption system or the high level of energy required for counteracting the stress (Salehi et al. 2018). An increment was also detected in the dry weight of shoots, roots, and flowers of chamomile (Bączek et al. 2019) due to the improved absorption, distribution of nutrients, the increment of proline, total soluble sugars, and antioxidant enzymes by AM, which improved the growth performance, lowered the stress damage, enhanced the plant growth and elevated the dry weight (Al-Arjani et al. 2020).

According to the results, the dry weight of chamomile shoots, roots, and flowers reduced under drought stress (Baghalian et al. 2011). Under drought stress, plant growth was reduced due to the reduction of osmotic regulation, osmotic imbalance, and the requirement of excessive energy needs to cope with stress (i.e. the production of osmolites and disruption of the nutrient uptake) (Munns et al. 1993). All nutrients play a vital role in plant growth; the nutrients (macro and micro) were positively correlated with the plant growth was positive (Daur et al. 2011). The effects of each nutrient on the uptake of other nutrients are very complex. According to the correlation shown in Fig. 4, the synergistic effect between many nutrients in chamomile reflects the diverse roles of these nutrients in the growth, yield, and uptake of other nutrients by chamomile. For example, sufficient $\mathrm{Mg}$ causes a proportional distribution of carbohydrates in the root and shoot; promoting the chamomile root growth (He et al., 2020). On the other hand, $\mathrm{Mg}$ affects biomass production and plant growth by proper distribution of carbohydrates and the appropriate allocation of hydrocarbons to different parts of plants (Verbruggen and Hermans 2013) or improving the plant access to $\mathrm{N}$ (Haberman et al. 2019) and iron (due to its vital role in photosynthesis) 
(Dong et al. 2019) with an effective role in vegetative growth and ultimately the accumulation of plant dry weight. This is consistent with a positive and high correlation of the dry weight of chamomile with the mentioned elements. According to the results, one of the most important causes of reduced growth of chamomile under stress conditions is the disturbed nutrients uptake (Salehi et al. 2018). The level of nutrients in the plant and the ability to uptake these nutrients are important factors in selecting the best cultivar under stress. In this regard, the Sor cultivar was almost superior to Bod in terms of both factors. On the other hand, improved absorption and distribution of elements as well as increased proline, total soluble sugar and antioxidant enzymes by mycorrhiza inoculation enhanced the growth while reducing stress-induced damages (Al-Arjani et al. 2020). In line with previous reports (Bączek et al. 2019), mycorrhiza increased the dry weight of shoots, roots, and flowers of chamomile.

\section{Conclusions}

Water-deficit stress increased the levels of the total soluble sugar, proline, and the activity of antioxidant enzymes (CAT, POD, and PPO) in both chamomile varieties. The amount of these enzymes and osmolytes was higher in the Soroksári variety as compared with the Bodgold variety. Water-deficit stress also reduced the uptake and transport of many nutrients from the roots to the shoots, which resulted in decreased content of nutrients such as $\mathrm{N}, \mathrm{P}, \mathrm{Fe}$, and $\mathrm{Mn}$ in the shoots of both varieties. Such a reduction of nutrients in the plant declined the plant dry weight under water-deficit stress, however, the dry weight of the shoot was higher in Soroksári variety under the control treatment and water potential of $-0.4 \mathrm{MPa}$ as compared with the Bod variety. AM + reduced the negative effects of drought stress on the plant through increasing the nutrients uptake, osmolytes contents and the activity of antioxidant enzymes.

\section{Abbreviations}

\section{AM}

Arbuscular mycorrhiza

\section{Bod}

Bodgold

Sor

Soroksári

N

Nitrogen

P

Phosphorus

$\mathrm{K}$

Potassium

\section{$\mathrm{Fe}$}

Iron 
Zinc

Cu

Copper

Mn

Manganese

CAT

Catalase

SOD

Superoxide dismutase

APX

Ascorbate peroxidase

ROS

Reactive oxygen species

+ AM

Plants inoculated with the arbuscular mycorrhiza fungus

-AM

Not inoculated with the arbuscular mycorrhiza fungus

DW

Dry weight

0

Osmotic potential

Var

Varieties

PPO

Polyphenol oxidase

\section{Declarations}

\section{Authors' contributions}

FE and AS designed the study, AS, MMD and FE performed experiments; FE, SH, MH and AM wrote the manuscript; all authors commented on the manuscript; All authors read and approved the final manuscript.

\section{Acknowledgment}

The authors are very grateful to Yasouj University, Iran for funded this study.

\section{Conflict of interest}

The authors acknowledge that there was no conflict of interest in performing this study or analyzing its results. 
Availability of data and materials

Not applicable.

\section{Ethics approval and consent to participate}

Not applicable.

\section{Consent for publication}

Not applicable.

\section{References}

1. Aalipour H, Nikbakht A, Etemadi N, Rejali F, Soleimani M (2020) Biochemical response and interactions between arbuscular mycorrhizal fungi and plant growth promoting rhizobacteria during establishment and stimulating growth of Arizona cypress (Cupressus arizonica G.) under drought stress. Sci Hortic 261:108923. https://doi.org/10.1016/j.scienta.2019.108923

2. Abbaspour $\mathrm{H}$ (2010) Investigation of the effects of vesicular arbuscular mycorrhiza on mineral nutrition and growth of Carthamus tinctorius under salt stress conditions. Russ J Plant Physiol 57(4):526-531. https://doi.org/10.1016/j.jplph.2012.01.014

3. Abbaspour H, Saeidi-Sa S, Afshari H, Abdel-Wahhab M (2012) Tolerance of mycorrhiza infected pistachio (Pistacia vera L.) seedling to drought stress under glasshouse conditions. Journal of plant physiolog 169(7):704-709. https://doi.org/10.1016/j.jplph.2012.01.014

4. Aebi H (1984) Catalase in vitro. Methods Enzymol 105:121-126. https://doi.org/10.1016/S00766879(84)05016-3

5. Al-Arjani AB, F, Hashem A, Abd_Allah EF (2020) Arbuscular mycorrhizal fungi modulates dynamics tolerance expression to mitigate drought stress in Ephedra foliata Boiss. Saudi journal of biological sciences 27(1):380-394. https://doi.org/10.1016/j.sjbs.2019.10.008

6. Amiri R, Nikbakht A, Etemadi N (2015) Alleviation of drought stress on rose geranium [Pelargonium graveolens (L.) Herit.] in terms of antioxidant activity and secondary metabolites by mycorrhizal inoculation. Sci Hortic 197:373-380. https://doi.org/10.1016/j.scienta.2015.09.062

7. Andrzejewska J, Woropaj-Janczak M (2014) German chamomile performance after stubble catch crops and response to nitrogen fertilization. Ind Crops Prod 62:350-358. https://doi.org/10.1016/j.indcrop.2014.09.004

8. Armada E, Probanza A, Roldán A, Azcón R (2016) Native plant growth promoting bacteria Bacillus thuringiensis and mixed or individual mycorrhizal species improved drought tolerance and oxidative metabolism in Lavandula dentata. plants Journal of plant physiology 192:1-12. https://doi.org/10.1016/j.jplph.2015.11.007 
9. Ashraf M, Foolad MR (2007) Roles of glycine betaine and proline in improving plant abiotic stress resistance. Environ Exp Bot 59(2):206-216. https://doi.org/10.1016/j.envexpbot.2005.12.006

10. Asrar AWA, Elhindi KM (2011) Alleviation of drought stress of marigold (Tagetes erecta) plants by using arbuscular mycorrhizal fungi. Saudi journal of biological sciences 18(1):93-98. https://doi.org/10.1016/j.sjbs.2010.06.007

11. Attarzade M, Balouchi H, Rajaie M, Dehnavi MM, Salehi A (2019a) Growth and nutrient content of Echinacea purpurea as affected by the combination of phosphorus with arbuscular mycorrhizal fungus and Pseudomonas florescent bacterium under different irrigation regimes. Journal of environmental management 231:182-188. https://doi.org/10.1016/j.jenvman.2018.10.040

12. Attarzadeh M, Balouchi H, Rajaie M, Dehnavi MM, Salehi A (2019b) Improvement of Echinacea purpurea performance by integration of phosphorus with soil microorganisms under different irrigation regimes. Agric Water Manag 221:238-247. https://doi.org/10.1016/j.agwat.2019.04.022

13. Augé RM (2001) Water relations, drought and vesicular-arbuscular mycorrhizal symbiosis. Mycorrhiza 11(1):3-42

14. Bączek KB, Wiśniewska M, Przybył JL, Kosakowska O, Węglarz Z (2019) Arbuscular mycorrhizal fungi in chamomile (Matricaria recutita L.) organic cultivation. Ind Crops Prod 140:111562. https://doi.org/10.1016/j.indcrop.2019.111562

15. Baghalian K, Abdoshah S, Khalighi-Sigaroodi F, Paknejad F (2011) Physiological and phytochemical response to drought stress of German chamomile (Matricaria recutita L.). Plant Physiol Biochem 49(2):201-207. https://doi.org/10.1016/j.plaphy.2010.11.010

16. Benabdellah K, Abbas Y, Abourouh M, Aroca R, Azcón R (2011) Influence of two bacterial isolates from degraded and non-degraded soils and arbuscular mycorrhizae fungi isolated from semi-arid zone on the growth of Trifolium repens under drought conditions: Mechanisms related to bacterial effectiveness. European Journal of Soil Biology 47(5):303-309. https://doi.org/10.1016/j.ejsobi.2011.07.004

17. Chapman H, Prat P (1961) Methods of analysis for soil plant and water, USA: Division of Agriculture Science. University of California, Riverside. CA, 1188

18. Chavoushi M, Najafi F, Salimi A, Angaji S (2019) Improvement in drought stress tolerance of safflower during vegetative growth by exogenous application of salicylic acid and sodium nitroprusside. Ind Crops Prod 134:168-176. https://doi.org/10.1016/j.indcrop.2019.03.071

19. Daur I, Sepetoğlu H, Sindel B (2011) Dynamics of faba bean growth and nutrient uptake and their correlation with grain yield. Journal of plant nutrition 34(9):1360-1371. https://doi.org/10.1080/01904167.2011.580878

20. Dehghanian H, Halajnia A, Lakzian A, Astaraei AR (2018) The effect of earthworm and arbuscular mycorrhizal fungi on availability and chemical distribution of $\mathrm{Zn}$, Fe and $\mathrm{Mn}$ in a calcareous soil. Appl Soil Ecol 130:98-103. https://doi.org/10.1016/j.apsoil.2018.06.002

21. Dinauer R (1982) Methods of soil analysis. ASA, SSSA. Madison, Wisconsin (USA) 
22. Dong Y, Wan Y, Liu F, Zhuge Y (2019) Effects of exogenous SA supplied with different approaches on growth, chlorophyll content and antioxidant enzymes of peanut growing on calcareous soil. J Plant Nutr 42(16):1869-1883. https://doi.org/10.1080/01904167.2019.1648679

23. Doubková P, Vlasáková E, Sudová R (2013) Arbuscular mycorrhizal symbiosis alleviates drought stress imposed on Knautia arvensis plants in serpentine soil. Plant Soil 370(1):149-161

24. Ekor M (2014) The growing use of herbal medicines: issues relating to adverse reactions and challenges in monitoring safety. Front Pharmacol 4:177. https://doi.org/10.3389/fphar.2013.00177

25. Ghobadi M, Taherabadi S, Ghobadi ME, Mohammadi GR, Jalali-Honarmand S (2013) Antioxidant capacity, photosynthetic characteristics and water relations of sunflower (Helianthus annuus L.) cultivars in response to drought stress. Ind Crops Prod 50:29-38.

https://doi.org/10.1016/j.indcrop.2013.07.009

26. Gholamhoseini M, Ghalavand A, Dolatabadian A, Jamshidi E, Khodaei-Joghan A (2013) Effects of arbuscular mycorrhizal inoculation on growth, yield, nutrient uptake and irrigation water productivity of sunflowers grown under drought stress. Agric Water Manag 117:106-114. https://doi.org/10.1016/j.agwat.2012.11.007

27. Gosztola B, Sáros S, Németh'E (2010) Variability of the essential oil content and composition of chamomile (Matricaria recutita L.) affected by weather conditions. Nat Prod Commun 5(3): 1934578X1000500325. https://doi.org/10.1177\%2F1934578X1000500325

28. Haberman A, Dag A, Shtern N, Zipori I, Erel R, Ben-Gal A, Yermiyahu U (2019) Significance of proper nitrogen fertilization for olive productivity in intensive cultivation. Sci Hortic 246:710-717. https://doi.org/10.1016/j.scienta.2018.11.055

29. Halo BA, Al-Yahyai RA, Al-Sadi AM (2020) An endophytic Talaromyces omanensis enhances reproductive, physiological and anatomical characteristics of drought-stressed tomato. Journal of plant physiology 249:153163. https://doi.org/10.1016/j.jplph.2020.153163

30. Hameed A, Wu QS, Abd-Allah EF, Hashem A, Kumar A, Lone HA, Ahmad P (2014) Role of AM fungi in alleviating drought stress in plants. In: Use of microbes for the alleviation of soil stresses. Springer, pp 55-75

31. Hashem A, Kumar A, Al-Dbass AM, Alqarawi AA, Al-Arjani AB, F, Singh G, Farooq M, Abd_Allah EF (2019) Arbuscular mycorrhizal fungi and biochar improves drought tolerance in chickpea. Saudi Journal of Biological Sciences 26(3):614-624. https://doi.org/10.1016/j.sjbs.2018.11.005

32. He H, Jin X, Ma H, Deng Y, Huang J, Yin L (2020) Changes of plant biomass partitioning, tissue nutrients and carbohydrates status in magnesium-deficient banana seedlings and remedy potential by foliar application of magnesium. Sci Hortic 268:109377. https://doi.org/10.1016/j.scienta.2020.109377

33. Hu J, Chan PT, Wu F, Wu S, Zhang J, Lin X, Wong MH (2013) Arbuscular mycorrhizal fungi induce differential $\mathrm{Cd}$ and $\mathrm{P}$ acquisition by Alfred stonecrop (Sedum alfredii Hance) and upland kangkong (Ipomoea aquatica Forsk.) in an intercropping system. Applied soil ecology 63:29-35. https://doi.org/10.1016/j.apsoil.2012.09.002 
34. Irigoyen J, Einerich D, Sánchez-Díaz M (1992) Water stress induced changes in concentrations of proline and total soluble sugars in nodulated alfalfa (Medicago sativd) plants. Physiol Plant 84(1):55-60. https://doi.org/10.1111/j.1399-3054.1992.tb08764.x

35. Kahn V (1975) Polyphenol oxidase activity and browning of three avocado varieties. J Sci Food Agric 26(9):1319-1324. https://doi.org/10.1002/jsfa.2740260910

36. Khan MIR, Fatma M, Per TS, Anjum NA, Khan NA (2015) Salicylic acid-induced abiotic stress tolerance and underlying mechanisms in plants. Frontiers in plant science 6:462

37. Khanna-Chopra R, Selote DS (2007) Acclimation to drought stress generates oxidative stress tolerance in drought-resistant than-susceptible wheat cultivar under field conditions. Environ Exp Bot 60(2):276-283. https://doi.org/10.1016/j.envexpbot.2006.11.004

38. Knudsen D, Peterson G, Pratt P. . Page AL, Miller RH, Keeney (1982) Lithium, sodium, and potassium. In: Methods of Soil Analysis Part 2." Chemical and microbiological properties". DR. Am. Soc. Agron. Madison, Wisconsin

39. Kong J, Pei Z, Du M, Sun G, Zhang X (2014) Effects of arbuscular mycorrhizal fungi on the drought resistance of the mining area repair plant Sainfoin. International Journal of Mining Science Technology 24(4):485-489. https://doi.org/10.1016/j.jimst.2014.05.011

40. Lehmann A, Veresoglou SD, Leifheit EF, Rillig MC (2014) Arbuscular mycorrhizal influence on zinc nutrition in crop plants-a meta-analysis. Soil Biol Biochem 69:123-131. https://doi.org/10.1016/j.soilbio.2013.11.001

41. Madani K, AghaKouchak A, Mirchi A (2016) Iran's socio-economic drought: challenges of a waterbankrupt nation. Iranian Studies 49(6):997-1016. https://doi.org/10.1080/00210862.2016.1259286

42. Meddich A, Jaiti F, Bourzik W, El Asli A, Hafidi M (2015) Use of mycorrhizal fungi as a strategy for improving the drought tolerance in date palm (Phoenix dactylifera). Sci Hortic 192:468-474. https://doi.org/10.1016/j.scienta.2015.06.024

43. Michel BE, Kaufmann MR (1973) The osmotic potential of polyethylene glycol 6000. Plant physiology 51(5):914-916. https://doi.org/10.1104/pp.51.5.914

44. Monreal J, Jimenez E, Remesal E, Morillo-Velarde R, García-Mauriño S, Echevarría C (2007) Proline content of sugar beet storage roots: Response to water deficit and nitrogen fertilization at field conditions. Environ Exp Bot 60(2):257-267. https://doi.org/10.1016/j.envexpbot.2006.11.002

45. Mouradi M, Bouizgaren A, Farissi M, Latrach L, Qaddoury A, Ghoulam C (2016) Seed osmopriming improves plant growth, nodulation, chlorophyll fluorescence and nutrient uptake in alfalfa (Medicago sativa L.)-rhizobia symbiosis under drought stress. Sci Hortic 213:232-242. https://doi.org/10.1016/j.scienta.2016.11.002

46. Munns R (1993) Physiological processes limiting plant growth in saline soils: some dogmas and hypotheses. Plant Cell Environment 16(1):15-24. https://doi.org/10.1111/j.13653040.1993.tb00840.x

47. Mustafa G, Khong NG, Tisserant B, Randoux B, Fontaine J, Magnin-Robert M, Reignault P, Sahraoui A. L H (2017) Defence mechanisms associated with mycorrhiza-induced resistance in wheat against 
powdery mildew. Funct Plant Biol 44(4):443-454. https://doi.org/10.1071/FP16206

48. Nouraei S, Rahimmalek M, Saeidi G (2018) Variation in polyphenolic composition, antioxidants and physiological characteristics of globe artichoke (Cynara cardunculus var. scolymus Hayek L.) as affected by drought stress. Sci Hortic 233:378-385. https://doi.org/10.1016/j.scienta.2017.12.060

49. Novamsky I, Van Eck R, Van Schouwenburg C, Walinga I (1974) Total nitrogen determination in plant material by means of the indophenol-blue method. NJAS wageningen journal of life sciences 22(1):3-5. https://doi.org/10.18174/njas.v22i1.17230

50. Paquin R, Lechasseur P (1979) Observations sur une méthode de dosage de la proline libre dans les extraits de plantes. Can J Bot 57(18):1851-1854. https://doi.org/10.1139/b79-233

51. Rehmat S, Khera RA, Hanif MA, Ayub MA, Zubair M (2020) Chamomilla. In Medicinal Plants of South Asia (pp. 101-112) Elsevier. https://doi.org/10.1016/B978-0-08-102659-5.00008-2

52. Ruiz-Lozano J, Azcón R, Gomez M (1995) Effects of arbuscular-mycorrhizal glomus species on drought tolerance: physiological and nutritional plant responses. Appl Environ Microbiol 61(2):456460

53. Salehi A, Tasdighi H, Gholamhoseini M (2016) Evaluation of proline, chlorophyll, soluble sugar content and uptake of nutrients in the German chamomile (Matricaria chamomilla L.) under drought stress and organic fertilizer treatments. Asian Pacific Journal of Tropical Biomedicine 6(10):886891. https://doi.org/10.1016/j.apjtb.2016.08.009

54. Selmar D, Kleinwächter M, Abouzeid S, Yahyazadeh M, Nowak M (2017) The impact of drought stress on the quality of spice and medicinal plants. In: Medicinal plants and environmental challenges. Springer, pp 159-175

55. Sharifi F, Simbar M, Mojab F, Majd HA (2014) Comparison of the effects of Matricaria chamomila (Chamomile) extract and mefenamic acid on the intensity of premenstrual syndrome. Complement Ther Clin Pract 20(1):81-88. https://doi.org/10.1016/j.ctcp.2013.09.002

56. Sharma A (2004) Global medicinal plants demand may touch \$5 trillion by 2050. Indian Express, 29

57. Thipyapong P, Melkonian J, Wolfe W, Steffens JC (2004) Suppression of polyphenol oxidases increases stress tolerance in tomato. Plant Sci 167(4):693-703.

https://doi.org/10.1016/j.plantsci.2004.04.008

58. Tsivelik N, Sarrou E, Gusheva K, Pankou C, Koutsos T, Chatzopoulou P, Mavromatis A (2018) Phenotypic variation of wild Chamomile (Matricaria chamomilla L.) populations and their evaluation for medicinally important essential oil. Biochem Syst Ecol 80:21-28.

https://doi.org/10.1016/j.bse.2018.06.001

59. Tyagi J, Varma A, Pudake RN (2017) Evaluation of comparative effects of arbuscular mycorrhiza (Rhizophagus intraradices) and endophyte (Piriformospora indica) association with finger millet (Eleusine coracana) under drought stress. European Journal of Soil Biology 81:1-10. https://doi.org/10.1016/j.ejsobi.2017.05.007

60. Uzilday B, Turkan I, Sekmen AH, Ozgur R, Karakaya H (2012) Comparison of ROS formation and antioxidant enzymes in Cleome gynandra (C4) and Cleome spinosa (C3) under drought stress. Plant 
Sci 182:59-70. https://doi.org/10.1016/j.plantsci.2011.03.015

61. Verbruggen N, Hermans C (2013) Physiological and molecular responses to magnesium nutritional imbalance in plants. Plant soil 368(1):87-99

62. Wang WG, Li R, Liu B, Li L, Wang SH, Chen F (2011) Effects of low nitrogen and drought stresses on proline synthesis of Jatropha curcas seedling. Acta Physiol Plant 33(5):1591-1595

63. Wichtl M (2004) Herbal drugs and phytopharmaceuticals: a handbook for practice on a scientific basis. Medpharm GmbH Scientific Publishers

64. Wu QS, Srivastava AK, Zou YN (2013) AMF-induced tolerance to drought stress in citrus: a review. Sci Hortic 164:77-87. https://doi.org/10.1016/j.scienta.2013.09.010

65. Wu Q, Zou Y (2009) Mycorrhiza has a direct effect on reactive oxygen metabolism of droughtstressed citrus. Plant Soil Environment 55(10):436-442

66. Wu Q, Zou Y (2009) Mycorrhizal influence on nutrient uptake of citrus exposed to drought stress. Philippine Agricultural Scientist 92(1):33-38

67. Yooyongwech S, Samphumphuang T, Tisarum R, Theerawitaya C, Cha-Um S (2016) Arbuscular mycorrhizal fungi (AMF) improved water deficit tolerance in two different sweet potato genotypes involves osmotic adjustments via soluble sugar and free proline. Sci Hortic 198:107-117. https://doi.org/10.1016/j.scienta.2015.11.002

68. Zardak SG, Dehnavi MM, Salehi A, Gholamhoseini M (2018) Effects of using arbuscular mycorrhizal fungi to alleviate drought stress on the physiological traits and essential oil yield of fennel. Rhizosphere 6:31-38. https://doi.org/10.1016/j.scienta.2015.11.002

69. Zhang F, Zou YN, Wu QS (2018) Quantitative estimation of water uptake by mycorrhizal extraradical hyphae in citrus under drought stress. Sci Hortic 229:132-136. https://doi.org/10.1016/j.scienta.2017.10.038

70. Zhao Q, Guo J, Shu M, Wang P, Hu S (2020) Impacts of drought and nitrogen enrichment on leaf nutrient resorption and root nutrient allocation in four Tibetan plant species. Sci Total Environ 723:138106. https://doi.org/10.1016/j.scitotenv.2020.138106

71. Zhao R, Guo W, Bi N, Guo J, Wang L, Zhao J, Zhang J (2015) Arbuscular mycorrhizal fungi affect the growth, nutrient uptake and water status of maize (Zea mays L.) grown in two types of coal mine spoils under drought stress. Appl Soil Ecol 88:41-49. https://doi.org/10.1016/j.apsoil.2014.11.016

72. Zhou W, Leul M (1999) Uniconazole-induced tolerance of rape plants to heat stress in relation to changes in hormonal levels, enzyme activities and lipid peroxidation. Plant Growth Regul 27(2):99104

\section{Tables}


tnalysis of variance of arbuscular mycorrhiza, variety and osmotic potential effects on nutrients uptake ımile

\begin{tabular}{|c|c|c|c|c|c|c|c|c|c|c|c|c|c|c|}
\hline \multirow[t]{2}{*}{ : of variation } & \multicolumn{7}{|c|}{ Shoot concentration } & \multicolumn{7}{|c|}{ Root concentration } \\
\hline & $\mathrm{N}$ & $\mathrm{P}$ & K & $\mathrm{Zn}$ & $\mathrm{Fe}$ & $\mathrm{Cu}$ & Mn & $\mathrm{N}$ & $\mathrm{P}$ & K & $\mathrm{Zn}$ & $\mathrm{Fe}$ & $\mathrm{Cu}$ & $\mathrm{Mn}$ \\
\hline $\mathrm{O}$ & ** & $* *$ & $* *$ & $* *$ & $* *$ & $* *$ & $* *$ & $* *$ & $* *$ & $* *$ & $* *$ & ** & $* *$ & $* *$ \\
\hline $\mathrm{AM}$ & $* *$ & $* *$ & $* *$ & $* *$ & $* *$ & $* *$ & $* *$ & $* *$ & $* *$ & $* *$ & $* *$ & $* *$ & $* *$ & $* *$ \\
\hline Var & ** & $* *$ & ** & $* *$ & $* *$ & $* *$ & $* *$ & $* *$ & $* *$ & $* *$ & $* *$ & $* *$ & $* *$ & $* *$ \\
\hline $\mathrm{O} \times \mathrm{AM}$ & $* *$ & $* *$ & ns & $* *$ & $* *$ & ns & ns & $* *$ & ns & $* *$ & ns & $* *$ & ns & $* *$ \\
\hline כ×Var & $* *$ & $* *$ & $* *$ & $*$ & $* *$ & ns & $* *$ & ns & $* *$ & $* *$ & $* *$ & $* *$ & $*$ & $* *$ \\
\hline $\mathrm{M} \times \operatorname{Var}$ & $*$ & $* *$ & ns & ns & ns & $*$ & ns & $*$ & ns & $* *$ & ns & ns & ns & $* *$ \\
\hline AM×Var & $* *$ & $* *$ & ns & ns & $* *$ & ns & ns & $\mathrm{ns}$ & $\mathrm{ns}$ & $\mathrm{ns}$ & ns & ns & $\mathrm{ns}$ & $\mathrm{ns}$ \\
\hline
\end{tabular}

tic potential, Var: Varieties , AM: Arbuscular mycorrhizal inoculation, ns non-significance at $P \leq 0.05$; $\bar{j} ; * * \leq 0.01$, statistical significance

Analysis of variance of arbuscular mycorrhiza, variety, osmotic potential and their interactions on osmolytes, activity of antioxidant enzymes (catalase (CAT), peroxidase (POD) and polyphenol $(\mathrm{PPO}))$, and shoot and root dry weights

of variation Proline Total soluble sugar CAT POD PPO Shoot dry weight Root dry weight

\begin{tabular}{|c|c|c|c|c|c|c|c|}
\hline $\mathrm{O}$ & $* *$ & $* *$ & $* *$ & $* *$ & $* *$ & $* *$ & $* *$ \\
\hline $\mathrm{AM}$ & $* *$ & $* *$ & $* *$ & $* *$ & $* *$ & $* *$ & $* *$ \\
\hline Var & $* *$ & $* *$ & $* *$ & $* *$ & $* *$ & $* *$ & $* *$ \\
\hline )×AM & $* *$ & $* *$ & $* *$ & $* *$ & $* *$ & $* *$ & $*$ \\
\hline )×Var & $* *$ & $* *$ & $* *$ & $* *$ & $* *$ & $* *$ & $* *$ \\
\hline $\mathrm{M} \times \operatorname{Var}$ & $* *$ & ns & ns & $* *$ & $* *$ & $* *$ & $* *$ \\
\hline $\mathrm{AM} \times \operatorname{Var}$ & $* *$ & ns & $* *$ & $* *$ & $* *$ & $* *$ & $*$ \\
\hline
\end{tabular}

otic potential, Var: Varieties , AM: Arbuscular mycorrhizal inoculation, ns non-significance at $P \leq 0.05$ $.05 ; * * \leq 0.01$, statistical significance 
[able 3 Interaction effect of variety, osmotic potential and arbuscular mycorrhiza on nutrients uptake of shoot of chamomile

\begin{tabular}{|c|c|c|c|c|c|}
\hline & Treatments & & & t concent & ion \\
\hline $\begin{array}{l}\text { uscular } \\
\text { orrhiza }\end{array}$ & variety & $\begin{array}{l}\text { Osmotic } \\
\text { potential }\end{array}$ & $\begin{array}{c}\mathrm{N} \\
\left(\mathrm{mg} \cdot \mathrm{g}^{-1}\right)\end{array}$ & $\begin{array}{c}\mathrm{P} \\
\left(\mathrm{mg} \cdot \mathrm{g}^{-1}\right)\end{array}$ & $\begin{array}{c}\mathrm{Fe} \\
\left(\mathrm{mg} \cdot \mathrm{kg}^{-1}\right)\end{array}$ \\
\hline $\mathrm{Am}+$ & Bod & Control & $35.7^{b}$ & $12.6^{c}$ & $114.4^{a}$ \\
\hline $\mathrm{Am}-$ & Bod & Control & $33.6^{d}$ & $11.9^{e}$ & $101.9^{c}$ \\
\hline $\operatorname{tm}+$ & Bod & PEG-0.4 & $21.4^{f}$ & $12.4^{d}$ & $78.8^{\mathrm{e}}$ \\
\hline $\mathrm{tm}-$ & Bod & PEG-0.4 & $18.4^{\mathrm{g}}$ & $10.3^{\mathrm{h}}$ & $70.0^{\mathrm{f}}$ \\
\hline $\mathrm{tm}+$ & Bod & PEG-0.8 & $12.1^{\mathrm{i}}$ & $11.6^{\mathrm{f}}$ & $57.5^{\mathrm{h}}$ \\
\hline $\mathrm{Am}-$ & Bod & PEG-0.8 & $4.5^{\mathrm{j}}$ & $9.1^{\mathrm{j}}$ & $40.0^{j}$ \\
\hline $\operatorname{tm}+$ & Sor & Control & $37.2^{\mathrm{a}}$ & $14.2^{\mathrm{a}}$ & $113.1^{\mathrm{a}}$ \\
\hline $\mathrm{tm}-$ & Sor & Control & $34.4^{c}$ & $13.0^{\mathrm{b}}$ & $107.5^{b}$ \\
\hline $\operatorname{tm}+$ & Sor & PEG-0.4 & $24.6^{\mathrm{e}}$ & $12.9^{b}$ & $96.3^{d}$ \\
\hline Am- & Sor & PEG-0.4 & $20.9^{f}$ & $11.5^{\mathrm{f}}$ & $78.8^{e}$ \\
\hline $\operatorname{tm}+$ & Sor & PEG-0.8 & $18.6^{\mathrm{g}}$ & $10.6^{g}$ & $60.6^{\mathrm{g}}$ \\
\hline $\mathrm{tm}-$ & Sor & PEG-0.8 & $14.4^{\mathrm{h}}$ & $9.6^{\mathrm{i}}$ & $46.9^{i}$ \\
\hline $\begin{array}{l}\text { r-deficit } \\
\text { s inocula } \\
\text { rrhiza fi } \\
\text { I and So } \\
\text { icantly }\end{array}$ & $\begin{array}{l}\text { ess at three } \\
\text { d (+AM) o } \\
\text { rus } F \text {. moss } \\
\text { feri (Sor)) } \\
\text { fent at th }\end{array}$ & $\begin{array}{l}\text { Means follo } \\
\text { evel of } 5 \%\end{array}$ & $\begin{array}{l}\text { als (contro } \\
\text {-AM) wit } \\
\text { a chamom } \\
\text { a by comm } \\
\text { SD test) }\end{array}$ & $\begin{array}{l}0.4 \text {, and } \\
\text { le arbuscu } \\
\text { varieties } \\
\text { letter are }\end{array}$ & $\begin{array}{l}\text { MPa). } \\
\text { dgold } \\
\text { t }\end{array}$ \\
\hline
\end{tabular}


I Effect of osmotic potential, arbuscular mycorrhiza, and interaction of variety with arbuscular mycorrhiza on ts uptake of shoot and root of chamomile

\begin{tabular}{|c|c|c|c|c|c|c|c|c|c|}
\hline & \multicolumn{3}{|c|}{ Shoot concentration } & \multicolumn{4}{|c|}{ Root concentration } \\
\hline \multicolumn{3}{|c|}{ [reatments } & $\begin{array}{c}\mathrm{Cu} \\
\left(\mathrm{mg} \mathrm{kg}^{-1}\right)\end{array}$ & $\begin{array}{c}\mathrm{K} \\
\left(\mathrm{mg} \mathrm{g}^{-1}\right)\end{array}$ & $\begin{array}{c}\mathrm{Mn} \\
(\mathrm{mg} \mathrm{kg} \\
1)\end{array}$ & $\begin{array}{c}\mathrm{N} \\
\left(\mathrm{mg} \mathrm{g}^{-1}\right)\end{array}$ & $\begin{array}{c}\mathrm{P} \\
\left(\mathrm{mg} \mathrm{g}^{-1}\right)\end{array}$ & $\begin{array}{c}\mathrm{K} \\
\left(\mathrm{mg} \mathrm{g}^{-1}\right)\end{array}$ & $\begin{array}{c}\mathrm{Zn} \\
\left(\mathrm{mg} \cdot \mathrm{kg}^{-1}\right)\end{array}$ \\
\hline \multirow{9}{*}{ 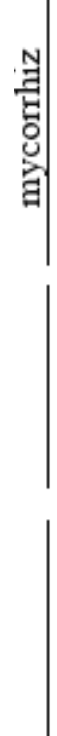 } & Bod & $\mathrm{Am}+$ & $67.5 \mathrm{~b}$ & $51.1 \mathrm{~b}$ & $68.9 \mathrm{~b}$ & $8.8 \mathrm{~b}$ & $13.8 \mathrm{~b}$ & $33.4 \mathrm{c}$ & $125.2 \mathrm{~b}$ \\
\hline & Bod & Am- & $55.6 \mathrm{c}$ & $46.4 d$ & $57.3 \mathrm{c}$ & $7.1 \mathrm{c}$ & $12.5 \mathrm{c}$ & $28.2 \mathrm{~d}$ & $106.9 \mathrm{~d}$ \\
\hline & Sor & $\mathrm{Am}+$ & $76.3 \mathrm{a}$ & $52.7 \mathrm{a}$ & $79.6 \mathrm{a}$ & $9.3 \mathrm{a}$ & $15.5 \mathrm{a}$ & $42.7 \mathrm{a}$ & $135.8 \mathrm{a}$ \\
\hline & Sor & Am- & $57.5 c$ & $49.1 \mathrm{c}$ & $58.3 \mathrm{c}$ & $7.2 \mathrm{c}$ & $13.8 \mathrm{~b}$ & $34.9 \mathrm{~b}$ & $118.8 \mathrm{c}$ \\
\hline & \multicolumn{2}{|c|}{ Control } & $76.7 \mathrm{a}$ & $38.7 \mathrm{c}$ & $76.4 \mathrm{a}$ & $11.0 \mathrm{a}$ & $11.0 \mathrm{c}$ & $21.4 \mathrm{c}$ & $185.3 \mathrm{a}$ \\
\hline & \multicolumn{2}{|c|}{ PEG-0.4 } & $65.3 b$ & $52.9 \mathrm{~b}$ & $73.8 \mathrm{a}$ & $8.6 \mathrm{~b}$ & $14.0 \mathrm{~b}$ & $34.3 \mathrm{~b}$ & $75.3 \mathrm{c}$ \\
\hline & \multicolumn{2}{|c|}{ PEG-0.8 } & $50.6 \mathrm{c}$ & $57.9 \mathrm{a}$ & $48.0 \mathrm{~b}$ & $4.7 \mathrm{c}$ & $16.7 \mathrm{a}$ & $48.7 \mathrm{a}$ & $104.4 \mathrm{~b}$ \\
\hline & \multicolumn{2}{|c|}{$\mathrm{AM}+$} & $71.9 \mathrm{a}$ & $51.9 \mathrm{a}$ & $74.2 \mathrm{a}$ & $9.0 \mathrm{a}$ & $14.7 \mathrm{a}$ & $38.1 \mathrm{a}$ & $130.5 \mathrm{a}$ \\
\hline & \multicolumn{2}{|c|}{ AM- } & $56.6 \mathrm{~b}$ & $47.8 \mathrm{~b}$ & $57.8 \mathrm{~b}$ & $7.2 \mathrm{~b}$ & $13.1 \mathrm{~b}$ & $31.6 \mathrm{~b}$ & $112.8 \mathrm{~b}$ \\
\hline
\end{tabular}

leficit stress at three osmotic potentials (control, -0.4 , and $-0.8 \mathrm{MPa}$ ). Plants inoculated (+AM) or not ted (-AM) with the arbuscular mycorrhiza fungus $F$. mosseae. Means followed by common letter are not antly different at the level of $5 \%$ (LSD test) 
Table 5 Effect of osmotic potential, and interaction of arbuscular mycorrhiza with variety on nutrients uptake of shoot and root of chamomile

\begin{tabular}{|c|c|c|c|c|c|c|c|c|c|c|c|c|}
\hline & \multicolumn{2}{|c|}{ Treatments } & \multicolumn{3}{|c|}{ Shoot concentration } & \multicolumn{7}{|c|}{ Root concentration } \\
\hline & & & $\begin{array}{c}\mathrm{K} \\
(\mathrm{mg} \mathrm{g} \\
\mathrm{l})\end{array}$ & $\begin{array}{c}\mathrm{Zn} \\
(\mathrm{mg} \\
\left.\mathrm{kg}^{-1}\right)\end{array}$ & $\begin{array}{c}\mathrm{Mn} \\
\left(\mathrm{mg} \mathrm{kg}^{-1}\right)\end{array}$ & $\begin{array}{c}\mathrm{N} \\
\left(\mathrm{mg} \mathrm{g}^{-1}\right)\end{array}$ & $\begin{array}{c}P \\
(\mathrm{mg} \mathrm{g} \\
1)\end{array}$ & $\underset{\left(\mathrm{mg} \mathrm{g}^{-}\right.}{\mathrm{K}}$ & $\begin{array}{l}\mathrm{Mn} \\
(\mathrm{mg} \\
\left.\mathrm{kg}^{-1}\right)\end{array}$ & $\begin{array}{c}\mathrm{Zn} \\
\left(\mathrm{mg} \mathrm{kg}^{-1}\right)\end{array}$ & $\begin{array}{c}\mathrm{Cu} \\
\left(\mathrm{mg} \mathrm{kg}^{-1}\right)\end{array}$ & $\begin{array}{c}\mathrm{Fe} \\
\left(\mathrm{mg} \mathrm{kg}^{-}\right. \\
\mathrm{l})\end{array}$ \\
\hline \multirow{6}{*}{ 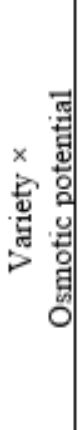 } & Bod & Control & $36.5 \mathrm{e}$ & $94.7 \mathrm{e}$ & $74.6 \mathrm{a}$ & $10.7 b$ & $9.7 \mathrm{e}$ & $18.6 \mathrm{f}$ & $64.1 \mathrm{~b}$ & $182.2 b$ & $64.6 \mathrm{~b}$ & $53.4 \mathrm{a}$ \\
\hline & Bod & PEG-0.4 & $51.8 \mathrm{c}$ & $227.5 b$ & $66.9 \mathrm{~b}$ & $8.6 \mathrm{c}$ & $13.2 \mathrm{c}$ & $30.1 d$ & $53.4 \mathrm{~d}$ & $73.4 \mathrm{e}$ & $55.9 \mathrm{~d}$ & $36.6 \mathrm{c}$ \\
\hline & Bod & PEG-0.8 & $58 \mathrm{a}$ & $142.5 \mathrm{c}$ & $47.8 \mathrm{c}$ & $4.5 \mathrm{e}$ & $16.5 \mathrm{a}$ & $43.7 b$ & $40.0 \mathrm{e}$ & $92.5 \mathrm{~d}$ & $34.0 \mathrm{e}$ & $19.7 \mathrm{e}$ \\
\hline & Sor & Control & $41 \mathrm{~d}$ & $102.5 \mathrm{~d}$ & $78.1 \mathrm{a}$ & $11.3 \mathrm{a}$ & $12.2 \mathrm{~d}$ & $24.33 \mathrm{e}$ & $68.1 \mathrm{a}$ & $188.4 \mathrm{a}$ & $67.1 \mathrm{a}$ & $53.4 \mathrm{a}$ \\
\hline & Sor & PEG-0.4 & $54 \mathrm{~b}$ & $238.4 a$ & $80.6 a$ & $8.7 \mathrm{c}$ & $14.7 \mathrm{~b}$ & $38.4 \mathrm{c}$ & $55.6 \mathrm{c}$ & $77.2 \mathrm{e}$ & $61.5 \mathrm{c}$ & $40.9 b$ \\
\hline & Sor & PEG-0.8 & $57.8 \mathrm{a}$ & $143.1 \mathrm{c}$ & $48.1 \mathrm{c}$ & $4.9 \mathrm{~d}$ & $17 \mathrm{a}$ & $53.7 \mathrm{a}$ & $39.4 \mathrm{e}$ & $116.3 \mathrm{c}$ & $35.0 \mathrm{e}$ & $21.9 \mathrm{~d}$ \\
\hline \multirow{6}{*}{ 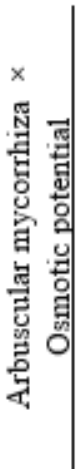 } & $\begin{array}{c}\mathrm{Am} \\
+\end{array}$ & Control & $40.8 \mathrm{~d}$ & $110.0 \mathrm{e}$ & $83.6 \mathrm{a}$ & $11.9 \mathrm{a}$ & $11.5 \mathrm{e}$ & $23.1 \mathrm{e}$ & $74.1 \mathrm{a}$ & $192.8 \mathrm{a}$ & $71.6 a$ & $55.9 \mathrm{a}$ \\
\hline & $\begin{array}{c}\mathrm{Am} \\
+\end{array}$ & PEG-0.4 & $55.0 \mathrm{~b}$ & $237.8 \mathrm{a}$ & $83.4 \mathrm{a}$ & $10.1 \mathrm{~b}$ & $14.9 \mathrm{c}$ & $38.1 \mathrm{c}$ & $57.5 b$ & $84.4 \mathrm{e}$ & $63.4 \mathrm{~b}$ & $43.4 \mathrm{c}$ \\
\hline & $\begin{array}{c}\mathrm{Am} \\
+\end{array}$ & PEG-0.8 & $60.0 \mathrm{a}$ & $155.6 \mathrm{c}$ & $55.6 \mathrm{c}$ & $5.2 \mathrm{~d}$ & $17.6 \mathrm{a}$ & $53.0 \mathrm{a}$ & $46.9 \mathrm{~d}$ & $114.4 \mathrm{c}$ & $40.0 \mathrm{e}$ & $22.8 \mathrm{e}$ \\
\hline & $\begin{array}{c}\mathrm{Am} \\
-\end{array}$ & Control & $36.7 \mathrm{e}$ & $87.2 \mathrm{f}$ & $69.1 \mathrm{~b}$ & $10.2 \mathrm{~b}$ & $10.5 \mathrm{f}$ & $19.8 \mathrm{f}$ & $58.1 \mathrm{~b}$ & $177.8 b$ & $60.3 \mathrm{c}$ & $50.9 b$ \\
\hline & $\begin{array}{c}\mathrm{Am} \\
-\end{array}$ & PEG-0.4 & $50.8 \mathrm{c}$ & $228.1 \mathrm{~b}$ & $64.1 \mathrm{~b}$ & $7.2 \mathrm{c}$ & $13.1 \mathrm{~d}$ & $30.5 \mathrm{~d}$ & $51.6 \mathrm{c}$ & $66.3 \mathrm{f}$ & $54.1 d$ & $34.1 d$ \\
\hline & $\mathrm{Am}$ & PEG-0.8 & $55.7 \mathrm{~b}$ & $130.0 \mathrm{~d}$ & $40.3 d$ & $4.1 \mathrm{e}$ & $15.8 \mathrm{~b}$ & $44.4 b$ & $32.5 \mathrm{e}$ & $94.4 \mathrm{~d}$ & $29.1 \mathrm{f}$ & $18.8 \mathrm{f}$ \\
\hline
\end{tabular}

Water-deficit stress at three osmotic potentials (control, -0.4 , and $-0.8 \mathrm{MPa}$ ). Plants inoculated (+AM) or not inoculated (-AM) with the arbuscular mycorrhiza fungus F. mosseae, two German chamomile varieties (Bodgold (Bod) and Soroksari (Sor)). Means followed by common letter are not significantly different at the level of 5\% (LSD test)

\section{Figures}



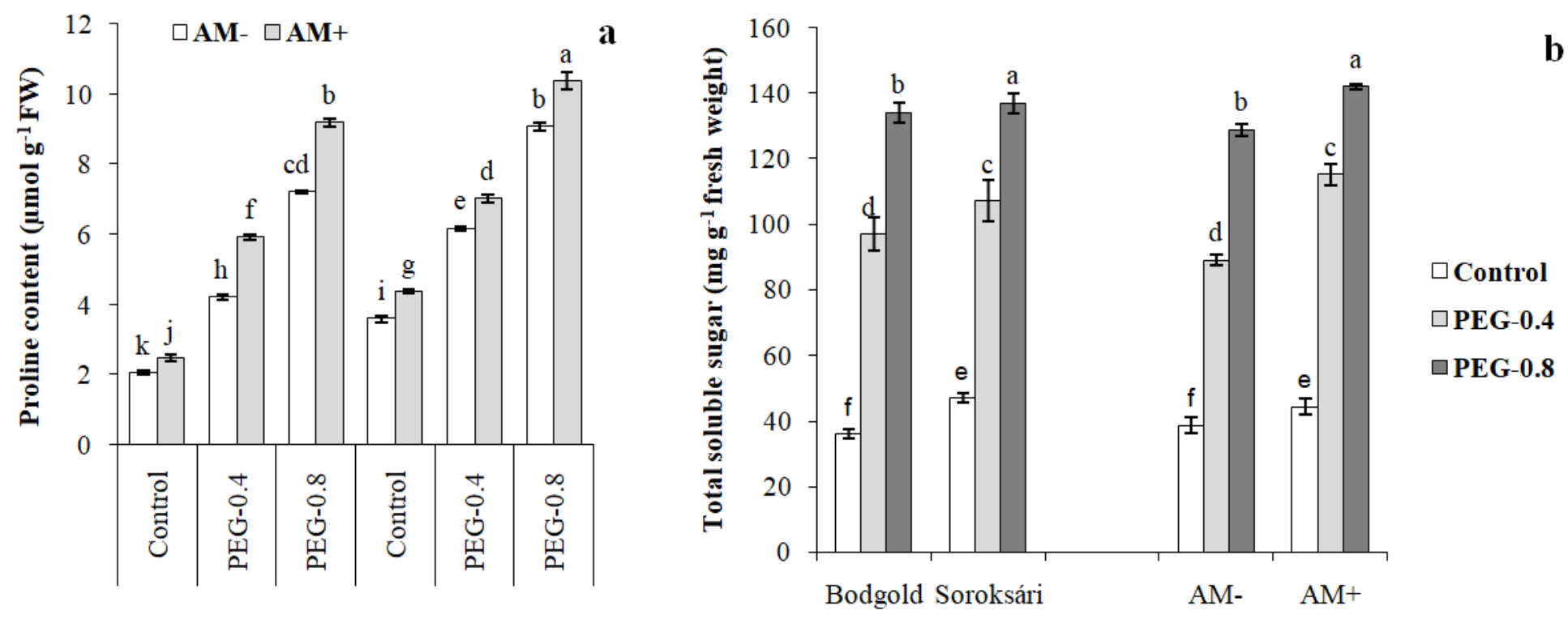

Figure 1

Interaction effect of osmotic potential (control, -0.4 , and $-0.8 \mathrm{MPa}) \times$ arbuscular mycorrhiza (AM) xvariety and on proline (a) and total soluble sugar (b) content of chamomile. Means within a column followed by the different letter are significantly different at $\mathrm{P}<0.05$. Standard error of the mean of total soluble sugar $(\mathrm{n}=6)$ and proline $(\mathrm{n}=3)$
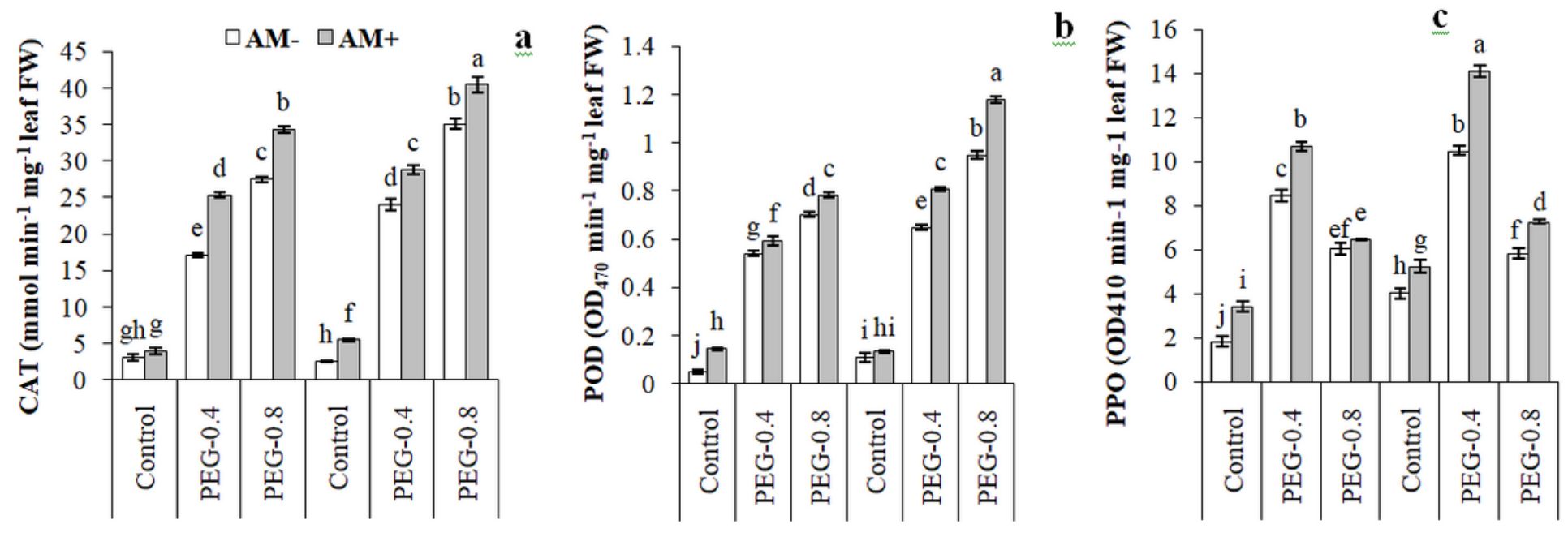

Figure 2

Interaction effect of osmotic potential (control, -0.4 , and $-0.8 \mathrm{MPa}) \times$ arbuscular mycorrhiza (AM) xvariety and on catalase (CAT)(a), peroxidase (POD)(b) and polyphenol oxidase (PPO) (c) activities of chamomile. Means within a column followed by the different letter are significantly different at $P<0.05$. Standard error of the mean $(n=3)$ 

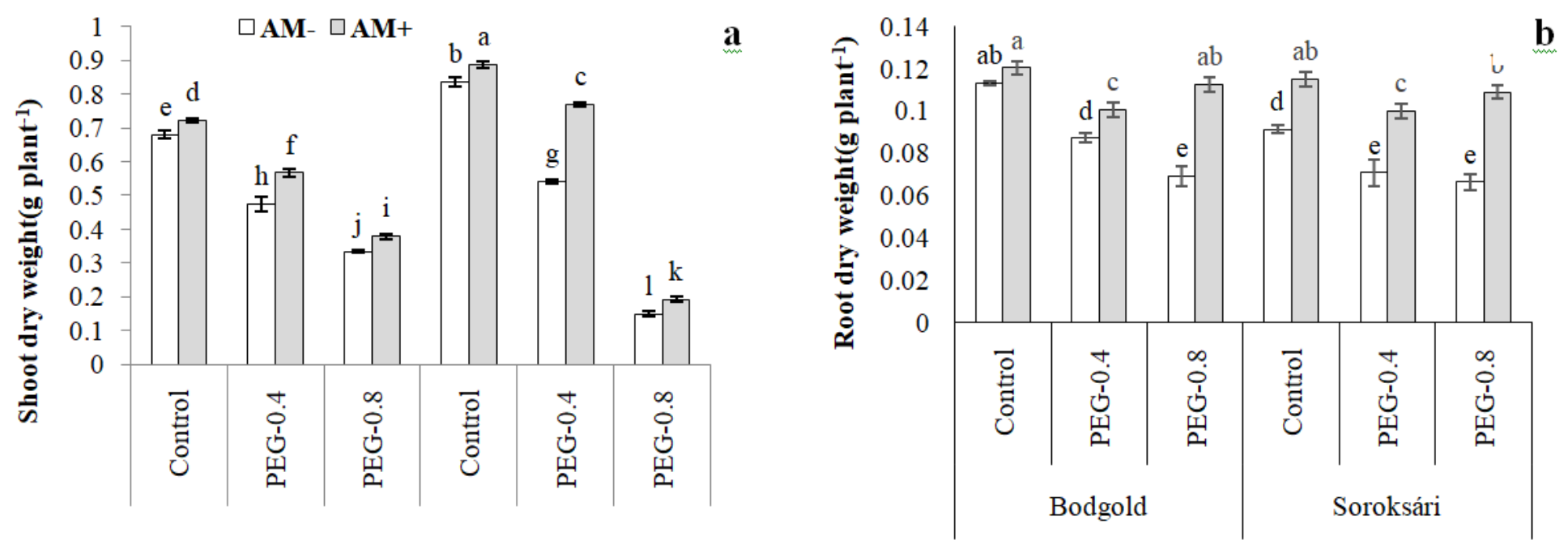

Figure 3

Interaction effect of osmotic potential(control, -0.4 , and $-0.8 \mathrm{MPa}) \times$ arbuscular mycorrhiza (AM) $\times$ variety and on dry weight of shoot (a), root (b). Means within a column followed by the different letter are significantly different at $P<0.05$. Standard error of the mean $(n=3)$ 